\title{
Acinar Cell
}

National Cancer Institute

\section{Source}

National Cancer Institute. Acinar Cell. NCI Thesaurus. Code C13077.

A secreting cell that lines an acinus (i.e. a small sac or sac-like structure). A representative example is the acinar cell located in the pancreas that produces pancreatic enzymes and juices. 